SCIENTIFIC REVIEW

\title{
THE IMPACT OF ORGANIZATIONAL CULTURE ON THE ULTIMATE PERFORMANCE OF A COMPANY
}

\section{Gordana Gavric, ${ }^{4}$ Goran Sormaz ${ }^{5}$, Djordje llic $^{6}$}

\begin{abstract}
The tendency towards the realization of profits, efficiency and growth of companies, emphasized in capitalism, has encouraged organizations to think about what is common for successful companies and what differentiates them from those considered unsuccessful. Thus, the organizational culture has become one of the most common themes in management theory and practice.

As a means of regulating the conduct of an organization's members, organizational culture permeates all of its factors, manifesting itself as a cause and as a consequence of their behavior. Naturally, its impact can be felt in all aspects of the business, reflecting itself on the final results.

Organizational culture should be cultivated, set in the function of company's success, but its negative impacts should be avoided.
\end{abstract}

KEY WORDS: Organizational Culture, Performance, Company

JEL: M14

UDC: 005.74

005.521:334.7

COBISS.SR-ID 227948300

\footnotetext{
${ }^{4}$ Corresponding author, Faculty of Business Economics and Entrepreneurship, Belgrade, Serbia, e-mail: gordana.gavric.bg@gmail.com

${ }_{5}^{5}$ Higher business school of vocational studies "Radomir Bojković PhD", Kruševac, Serbia

${ }^{6}$ Higher business school of vocational studies "Radomir Bojković PhD", Kruševac, Serbia
} 


\section{INTRODUCTION}

According to the opinion of Mats Alvesson (2002) there is a good reason for having organizational culture as one of the most common themes in academic research and education in organizational theory and management practice today: dimensions of culture is central to all aspects of organizational life. Organizational culture, as an integrative means of regulating the behavior of organization's members, permeates all of its activities, as a specific catalyst for the growth and development of a company.

By the mid-1980s companies operated in circumstances that involved security and stability. They were perceived as "...rational entities for coordination and controlling a group of people. They had vertical levels, organizational units, relations of authority" (Robbin, Judge, 2009). The work was settled in a certain way, without major changes today was the same as yesterday and it won't be different tomorrow? During this period, culture was the subject of interest only when a company would find itself in a difficult situation. It was not until the late 1980s that connecting the cultural aspects of the company with its success rate developed. Japanese companies known for their culture, made a boom with their productivity and began to suppress Western companies. It was a period of the oil crisis when Japanese companies achieved a dominant superiority thanks to their strong and cohesive culture. An interesting and important fact was that techniques of production and productivity applied by companies in Japan were imported from the United States. The Japanese successfully incorporated those techniques into their own culture and won. Japan's economic success lies in the homogeneous organizational culture and high standards of education. Some of the basic characteristics are flexibility, adaptability, and teamwork, while the Western business and organizational culture focuses exclusively on the functional effect of an individual.

Since then, the interest in organizational culture has not subsided. A few years later, Kotter and Heskett (1992) interviewed seventy-five highly regarded financial analysts whose job was to closely follow certain industries and corporations. Each analyst compared the performance of twelve highly successful firms to ten lower-performing firms. Although analysts are stereotyped as focusing almost exclusively on hard data, only one of the seventy-five indicated that culture had little or no impact on firm performance. All acknowledged culture as a critical factor in long-term financial success (Cameron, Quinn,2006).

Organizational culture became particularly important in early economic crisis and we believe that the interest in would grow in the future, given that managers consider the phenomenon of organizational culture essential for the competitiveness and stability of any organization. According to a survey conducted in 2009 in Germany among 157 managers, $45 \%$ of respondents indicated that the company culture had a high importance for success, and $24 \%$ that it had a very high (exceptional) importance (Leitl, Sackmann, Unternehmenskultur als Erfolgsfaktor. Harvard Business Manager, January 2010, pp. 40 41) (Rahimić, 2012).

Today, it is clear to almost all managers that the key to long-term success lies not in individual strategies and effective management of resources, but in, so far largely neglected dimension of governance, the cultural dimension (Cardona, Ray, 2009). In other words, in order to understand the source of competitive advantage of a company, one must understand its organizational culture (Janićijević, 1997). 


\section{THE PHENOMENON OF ORGANIZATIONAL CULTURE}

A few years ago, one of the managers was asked to define a concept of organizational culture, and he said, "I cannot define it, but I recognize it when I see it." (Robbins, Judge, 2009). Although it may be difficult to precisely determine and define organizational culture, we can describe it as a mysterious, vague but powerful force.

Organizational culture like "the operating system" leads an organization and its activities, shaping the way employees think, work and how they feel (Vukotić et al., 2014). An important feature of organizational culture is that at a certain point it can be effective, but it can be ineffective at some other point. Dysfunction of culture arises at a time of rapid changes when the consistency of behavior and deep-rooted values are no longer desirable. For example, companies in Serbia operated for decades in circumstances that involved safety (e.g. highly protected workers, job security etc.) and stability, which allowed them to work in a certain way, consistently, without changes. Thus, certain principles and values, which are applied in business and are difficult to deviate from, are deeply rooted in domestic companies. Principles and values inherited from the previous period, which are nowadays considered useless, are the major barrier to development of organizational culture in domestic companies. Peter Drucker also, in his article,"The Theory of the business", states that the largest number of companies in crisis have a system of values and beliefs that is not in accordance with the requirements of enterprises (Janićijević, 1997). Organizational culture should be cultivated, set in the function of company's success, but its negative impacts should be avoided.

Organizational culture can therefore be the wind at the back and the secret formula of enterprises' success, but also their silent killer. The fact that organizational culture can potentially have a negative impact on business operations increases the importance of its study and development multiple times. Unfortunately, experience shows that when things go well in an organization, managers are not interested and not involved enough in the organizational culture. Organizations that achieve great successes tend to believe that nothing can hurt or destroy them. But success often gives birth to the failure, especially in organizations with strong cultures (Miler, "What Happens After Success: The Perils of Excellence", Journal of Management Studies, 1994., p. 11-38) (Robbins, Judge, 2009). Robbins and Judge in their book,"Organizational Behavior" call those organizations that rapidly lose their competitive advantage due to their attitude arrogant organizations. Their cultures support practices of the past and make changes difficult, stressing that the corporate highway is crowded with wrecks of companies that allowed arrogance to undermine their earlier success. It is likely that some of these companies will eventually recover and stand on their own feet, but millions of profit and customers might have been lost forever, which is the high price they pay for their lack of adjustment.

In this respect, the link between organizational culture, operating results, and reputation of a company requires a responsible approach to this phenomenon as a proven powerful tool and key factor for achieving long-term success in any organization.

\section{THE EFFECT OF ORGANIZATIONAL CULTURE ON PERFORMANCE}

The fact is that today, given the hyper-competitiveness, attaining and maintaining competitiveness becomes increasingly difficult and uncertain. The situation is very clear: the organization will succeed or it will simply disappear from the market. Failure is not something that organizations seek voluntarily; instead, it usually turns out that the cause of 
failure is the lack of understanding of the importance of significant external factors or unrealized profit from organizational resources and capacity (Coulter, 2010).

The example that is often used to show the importance of organizational culture for doing business is the company Federal Express, known for the values shared by its employees. During the UPS strike in the summer of 1997, many new consumers turned to the company Fed Ex. After the company was overwhelmed with additional 800,000 parcels a day, thousands of employees came to the headquarters and volunteered to sort packages, clearly demonstrating the company's value in terms of providing service to the consumers. Only after the strike was over, the employees were awarded with additional salary related to the income earned during the strike (Jay et al., 2002).

A compliance of organization's management principles and its organizational culture is needed in order for a culture to be "a tailwind" to business success. The survey conducted in July 2014, in which over 500 global respondents took part, showed that $72 \%$ of them feel the culture is extremely important for organizational performance, while only $32 \%$ said that their organizational culture was aligned with their business strategy. Research has also shown that, despite the high rank of importance, only $25 \%$ think that they identify with the culture and to communicate their culture to a great extent, and only $35 \%$ believe that their employees are able to articulate their culture to a great extent (Eaton, Kilby, 2015).

Organizational culture of modern companies should primarily cultivate values such as knowledge, hard work, willingness to take risks, courage and creativity, as well as values that support the achievement of organizational values such as stability, productivity, and innovation. Out of fear of risks, many organizations make mistakes and remain conservative but operate at loss. We can use the example of Japanese car makers that have withdrawn from the placement of mini-vans to the US market after studies showed that they didn't receive the customers' support. Unlike them, the company Chrysler, which also conducted market research and received negative response, decided to take that risk, believing that some people would buy their products and that they would succeeded. And they did. It was one of the most profitable year in the history of Chrysler.

The following research results also corroborate the story about the power of organizational culture. In 1992, Harvard professors John Kotter and Jim Haskett presented the results of 11year comparison of successful and less successful companies. They have shown that those with strong distinctive culture (concentrated on customers, associates, managers and owners) can increase their profits by an average of $756 \%$, compared to a company with a less distinctive culture that can increase its profit only by $1 \%$. Also, according to the survey initiated by the Bundesministerium fuer Arbeit und Soziales, the combination of cultural dimensions (identification, team orientation, support of career development, mutual fairness and the ability to change the organization) could be explained by financial success up to $31 \%$. Thereby, culture particularly affects the engagement of staff, innovation and the subjective feelings of stress. Reasons for highly skilled associates leaving are connected with the culture of a company to 32\%. (Leitl,Sackmann S. Unternehmenskultur als Erfolgsfaktor; Harvard Business Manager, January 2010, p. 39;Rahimić, 2012).

A mission is one more important aspect of the organizational culture. Unclear missions as an image or label, or its absence makes the company to be left at the mercy of market forces (Gavrić, Stanković, 2015). In other words, the existence of a mission and its transparency has become essential for the successful functioning of any organization as a whole. In their work, Smith et al. (2003) highlight some studies reporting that after the creation and introduction of mission statement, company performance increases for about 50\% (Dermol, 2012). Bart et al. (2001) found that mission statements could positively affect employee behavior which had a direct effect on firm financial performance (Kofi Darbi, 2012). 
As mentioned earlier, the organizational culture begins to think seriously only when things go wrong, such as in the case of mergers and acquisitions, regardless if we talk about mergers at the national or international level. In those cases, the cultural differences come to the surface. At the international level, neglecting the culture of companies participating in the process of acquisitions and mergers, marks critical points of their success. As a proof of that, some experts say that $90 \%$ of merged corporations have never fulfilled expectations, and 50\% were sold within five years (Đokić, 2008). Their managers have successfully linked their financial and other systems of companies and production technology, but not the unwritten norms and values that guide them through business.

Also, the period of rapid growth of an organization or change of its strategy requires a focus on culture in order to maintain consistency in the business.

Inside of an organization, sub-units such as functional departments, product groups, hierarchical levels, or even teams, may also reflect their own unique cultures (Cameron, Quinn, 2006). Their own perspectives, set of values and principles of business can be the cause of conflict between them. This is another possible situation that could be inhibiting an organization and its performance.

The importance of organizational culture for business also lays in the fact that it forms a basis for development of business culture, which represents the ratio of an organization, i.e. its employees towards other business and organizational cultures at the domestic, but also at the global level. Developed commercial awareness allows to understand much of what it happening in the business environment, to what it happening fit into an existing framework and to successfully cope with business challenges.

\section{CONCLUSION}

The idea of observing organizational culture as a concept of great importance for operating of a company, is of a recent date. The importance of culture is reflected in the generally accepted attitude that a real organizational culture (one that suits business conditions) leads to success, and greater efficiency and effectiveness of company's operations and to its growth and development.

In order to successfully fit into the modern economic environment, some organizations have to change their organizational culture. For example, after struggling for survival, the Chrysler company has accepted a change of culture so that the entire process involved people focused on learning, put emphasis on quality and they once again became a successful and profitable company (Krouse, 2012).

Although changes can be a challenging and a long-term process for an organization, the rewards that follow are indisputable. Cameron and Quinn emphasize in their work, "Diagnosing and changing organizational culture; Based on competing values framework" (2006), without changing the culture there is little hope for lasting improvement in organizational performance. 


\section{REFERENCES}

[1] Alvesson, M. (2002). Understanding organization culture, SAGE Publications, London

[2] Cameron, S. K., Quinn, E. R. (2006). Diagnosing and changing organizational culture; Based on competing values framework, revised edition, The Jossey-Bass A Wiley Imprint, San Francisco

[3] Cardona, P., Rey, C. (2009) Upravljanje pomoću misija, Mate, Zagreb

[4] Coulter, M. (2010). Strategijski menadžment na delu, forth edition, Datastatus, Belgrade

[5] Dermol, V. (2012). Relationship between mission statement and company performance, Scientific Annals of the „Alexandru Ioan Cuza” University of Iaşi Economic Sciences 59 (1)

[6] Đokić, A. (2008). Organizaciono ponašanje skripta, Banja Luka

[7] Eaton, D., Kilby, G. (2015). Does Your Organizational Culture Support Your Business Strategy?, The Journal for Quality \& Participation, 4-7

[8] Gavrić, G., Stanković, R. (2015). The presence of factor of stability in organizations culture of organizations in Serbia, 4. International Scientific Conference "Employment, education and entrepreneurship", Faculty of Business Economics and Entrepreneurship, Belgrade, Serbia, 129-146

[9] Janićijević, N. (1997). Organizaciona kultura: kolektivni um preduzeća, ULIXES Novi Sad, Faculty of economics, Belgrade

[10] Jay, G., Downey, D., Kates, A. (2002). Designing Dynamic organizations, AMACOM

[11] Kofi Darbi, W. P. (2012). Of Mission and Vision Statements and Their Potential Impact on Employee Behaviour and Attitudes: The Case of A Public But ProfitOriented Tertiary Institution, International Journal of Business and Social Science, Vol. 3 No. 14, 95-109

[12] Krouse, H. (2012). Organizaciona kultura i preduzetništvo, International Review (2012 br.3-4), 27- 33

[13] Rahimić, Z., (2012).Organizaciona kultura kao nematerijalna strategija motiviranja zaposlenih, 6. International conference BAM 2012 - Knowledge management, 144152

[14] Robbins, P. S., Judge A. T. (2009). Organizacijsko ponašanje, 12th edition, Mate, Zagreb

[15] Vukotić, V., Šuković, D., Rašević, M., Maksimović, S., Goati, V. (editorial board) (2014). (Anti)liberalizam i ekonomija, Center for Economic Research of Institute of Social Sciences, Belgrade

\section{Article history:}

- $\quad$ Received

10 August 2016

- Accepted

15 October 2016 